\title{
Midazolam: an effective intravenous agent for seizure control
}

\author{
G. M. GALVIN \& G. A. JELINEK \\ Department of Emergency Medicine, Fremantle Hospital, Western Australia, Australia
}

\section{SUMMARY}

Midazolam maleate, a water soluble 1,4 benzodiazepine, was used intravenously in 20 patients suffering seizures, of whom 12 were in status epilepticus. In all cases, midazolam in a dose of $2.5-15 \mathrm{mg}$ rapidly terminated the seizure. There were no complications from the use of midazolam. The causes of the seizures were varied but alcohol-withdrawal seizures were the single largest cause. Thirteen patients were taking some form of anticonvulsant medication but only three were in the therapeutic range. Midazolam is seen to be an effective agent in the emergency treatment of seizures.

\section{INTRODUCTION}

Tonic-clonic seizures are a neurological emergency and need to be terminated quickly. Status epilepticus is defined as a seizure lasting more than $30 \mathrm{~min}$ or where a normal alert state is not regained between seizures. Clinical and experimental studies show that it is important to terminate tonic-clonic status epilepticus as soon as possible as it has been associated with brain damage and death (Delgado-Escueta et al., 1982).

\section{Benzodiazepines in seizure control}

Many sedatives, tranquillizers and anaesthetic agents have been shown to terminate seizures. In the $1920 \mathrm{~s}$, barbiturates became established as potent anti-convulsant agents. Naquet et al. (1965) reported the successful use of diazepam in experimental animals and man. Gastaut et al. (1965) published their results of the clinical use of diazepam in terminating seizures and from that time diazepam has been used extensively. The place of diazepam in seizure control was reviewed by Delgado-Escueta et al. (1982). Two other benzodiazepines, clonazepam and lorazepam have been used in

Correspondence: $\operatorname{Dr}$ G.M. Galvin, Department of Emergency Medicine, Fremantle Hospital, PO Box 480, 
seizure control. Clonazepam is effective as an oral agent in myoclonic epilepsy and hå been used intravenously in status epilepticus (Davidson, 1980). Lorazepam has a longe half-life than diazepam and has been used in the control of refractory neonatal seizures (Deshmukh et al., 1986). All benzodiazepines appear to modify excitability of neurond membranes by binding to specific receptor sites. The major effect of benzodiazepines seizures is potentiation of the GABA (inhibitory) pathway (Meldrum \& Chapmaris 1986; Sunao et al., 1983).

Diazepam has a long elimination half-life, $(21-37 \mathrm{~h})$, is water insoluble and require⿻ organic solvents to remain in solution. These solvents cause venous irritation an thrombophlebitis (Brown et al., 1979).

Recently, a water-soluble 1,4 benzodiazepine, midazolam, has become available for clinical use in Australia. Midazolam has an elimination-phase half-life of approximate $2 \mathrm{~h}$ and $30-40 \%$ of a single I.V. dose is recovered in a conjugated form in the urine in the first $12 \mathrm{~h}$. The effect of midazolam on E.E.G. recordings is similar to that ơf diazepam and Brown et al. (1979) suggested that the anticonvulsant properties of diazepam and midazolam would be similar and recommended further study to clarifo these points. Midazolam has been shown to protect mice from local-anaesthetio induced convulsions (DeJong \& Bonin, 1981). A case report in 1983 showed that midazolam was effective in controlling status epilepticus in a 14-year-old girl (Sunao of al., 1983). This trial was designed to test the efficacy of midazolam in seizure controt

\section{MATERIAL AND METHODS}

Twenty adult patients (13 years and over) who suffered seizures in the emergench department or who arrived in status epilepticus were treated with intravenous midaze lam. An initial dose of midazolam of $2.5 \mathrm{mg}$ was followed by increments until tho seizure was controlled. Blood was drawn from patients for blood alcohol and serum anticonvulsant levels.

Table 1 Details of patients and dose of midazolam

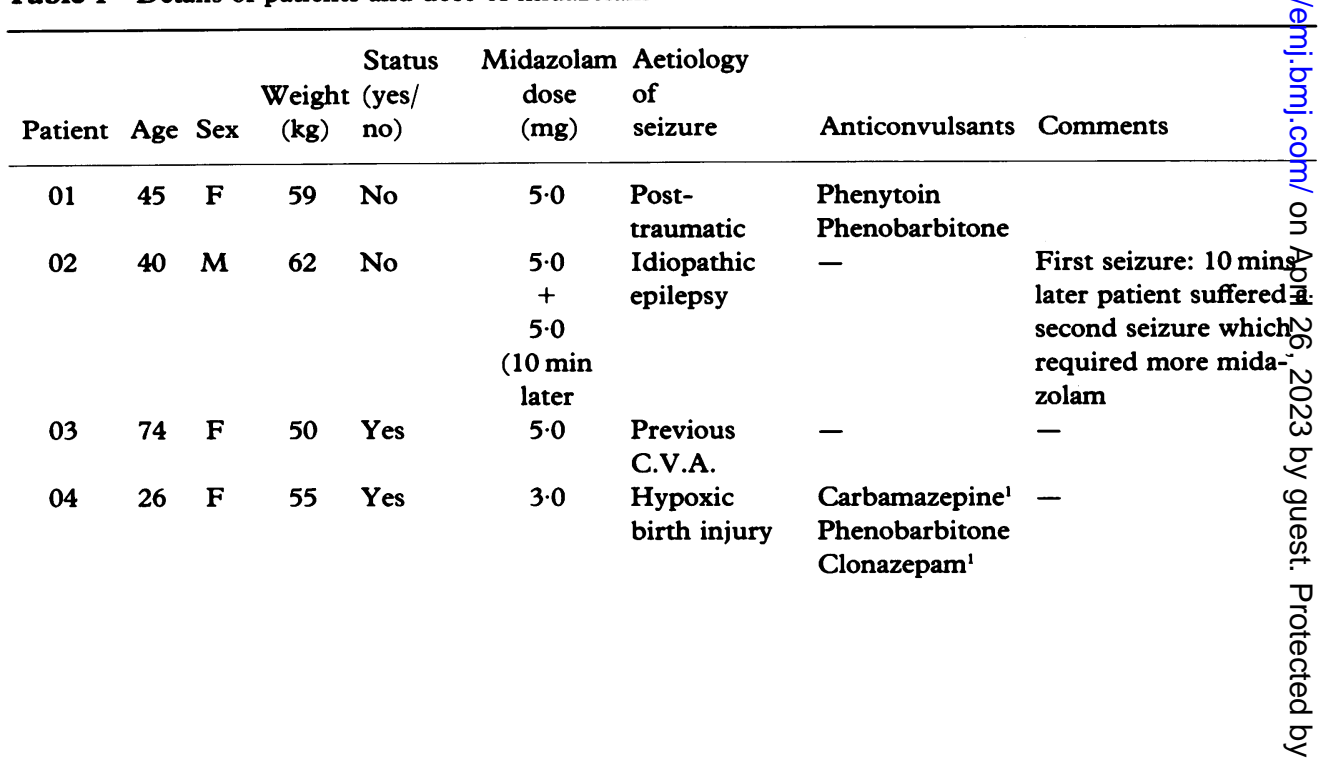




\begin{tabular}{|c|c|c|c|c|c|c|c|c|}
\hline 05 & 65 & $\mathbf{M}$ & 62 & No & $10 \cdot 0$ & $\begin{array}{l}\text { Idiopathic } \\
\text { epilepsy }\end{array}$ & - & - \\
\hline 06 & 53 & $\mathbf{M}$ & 65 & Yes & $7 \cdot 5$ & $\begin{array}{l}\text { Alcohol } \\
\text { withdrawal }\end{array}$ & - & - \\
\hline 07 & 20 & $\mathbf{M}$ & 50 & Yes & $4 \cdot 0$ & $\begin{array}{l}\text { Friedrich's } \\
\text { ataxia and } \\
\text { mental retar- } \\
\text { dation }\end{array}$ & Phenytoin ${ }^{1}$ & - \\
\hline 08 & 31 & $\mathbf{M}$ & 81 & Yes & & $\begin{array}{l}\text { Previous } \\
\text { cerebral } \\
\text { abscess }\end{array}$ & Phenytoin & - \\
\hline 09 & 55 & $\mathbf{M}$ & 43 & No & $5 \cdot 0$ & $\begin{array}{l}\text { Alcohol with- } \\
\text { drawal }\end{array}$ & Phenytoin & \\
\hline 10 & 61 & $\mathbf{F}$ & 72 & No & 5.0 & $\begin{array}{l}\text { Cerebral } \\
\text { metastases } \\
\text { (Ca Lung) }\end{array}$ & - & - \\
\hline 11 & 25 & $\mathbf{M}$ & 73 & Yes & $10 \cdot 0$ & $\begin{array}{l}\text { Myoclonic } \\
\text { epilepsy }\end{array}$ & $\begin{array}{l}\text { Valproate }^{2} \\
\text { Phenytoin }^{2} \\
\text { Clonazepam }^{2}\end{array}$ & $\begin{array}{l}\text { Drug levels not mea- } \\
\text { sured }\end{array}$ \\
\hline 12 & 71 & F & 43 & Yes & $15 \cdot 0$ & $\begin{array}{l}\text { Cerebral } \\
\text { metastases } \\
\text { (unknown } \\
\text { primary) }\end{array}$ & - & - \\
\hline 13 & 55 & $\mathbf{M}$ & 43 & No & 2.5 & $\begin{array}{l}\text { Alcohol } \\
\text { withdrawal }\end{array}$ & Phenytoin & \\
\hline 14 & 39 & $\mathbf{M}$ & 52 & Yes & $9 \cdot 0$ & $\begin{array}{l}\text { Post- } \\
\text { traumatic } \\
\text { epilepsy }\end{array}$ & Phenytoin & $\begin{array}{l}\text { Patient had been con- } \\
\text { vulsing for } 50 \text { min } \\
\text { prior to Midazolam }\end{array}$ \\
\hline 15 & 38 & $\mathbf{F}$ & 26 & No & $5 \cdot 0$ & $\begin{array}{l}\text { Mental } \\
\text { retardation } \\
\text { chromosome } \\
\text { 4-9 transloca- } \\
\text { tion }\end{array}$ & $\begin{array}{l}\text { Phenytoin } \\
\text { Carbamazepine }^{1}\end{array}$ & \\
\hline 16 & 64 & $\mathbf{M}$ & 110 & Yes & $7 \cdot 5$ & $\begin{array}{l}\text { Metabolic } \\
\text { (hypoglycae- } \\
\text { mia) }\end{array}$ & - & - \\
\hline 17 & 52 & $\mathbf{M}$ & 75 & No & $5 \cdot 0$ & $\begin{array}{l}\text { Alcohol } \\
\text { withdrawal }\end{array}$ & Phenytoin & - \\
\hline 18 & 74 & $\mathbf{M}$ & 120 & Yes & $5 \cdot 0$ & $\begin{array}{l}\text { Alcohol } \\
\text { withdrawal }\end{array}$ & Phenytoin & - \\
\hline 19 & 45 & $\mathbf{M}$ & 60 & Yes & $7 \cdot 5$ & $\begin{array}{l}\text { Alcohol } \\
\text { withdrawal }\end{array}$ & Phenytoin & - \\
\hline 20 & 49 & F & 56 & Yes & $7 \cdot 5$ & $\begin{array}{l}\text { Alcohol- } \\
\text { associated } \\
\text { epilepsy }\end{array}$ & Phenytoin $^{3}$ & $\begin{array}{l}\text { Phenytoin level in tox- } \\
\text { ic range }(38.0 \mathrm{mg} / \mathrm{ml}) \text {; } \\
\text { intoxicated B.A.L. } \\
0.12 \mathrm{~g} / \mathrm{dl}\end{array}$ \\
\hline
\end{tabular}

'Patients anticonvulsant level within the therapeutic range.

${ }^{2}$ Patients anticonvulsant levels not measured.

${ }^{3}$ Patients anticonvulsant level within the toxic range.

\section{RESULTS}

Control of seizures was achieved in less than one minute in all 20 patients, of whom 12 were in status epilepticus. 
No patient suffered any significant cardio-respiratory depression. Of the 13 patient taking anticonvulsants, only three had serum levels in the therapeutic range. Onez patient was in the toxic range for phenytoin and intoxicated with alcohol (patient 20)?

(Table 1).

\section{DISCUSSION}

Previous studies have suggested that midazolam would share anticonvulsant properties $\vec{\circ}$ with diazepam. In this study, midazolam has been shown to be an effective agent for $\overrightarrow{-}$ emergency seizure control. It was effective over a wide range of ages (20-74 years) ando weights $(26-120 \mathrm{~kg})$. The effective dose of midazolam lay between 2.5 and $15 \mathrm{mg}$ with $\stackrel{9}{3}$ mean dose of $8.25 \mathrm{mg}$.

Further studies are being undertaken.

\section{REFERENCES}

Brown C. R., Sarnquist F. H., Canup C. A. \& Pedley T. A. (1979) Clinical, electroencephalographic and pharmacokinetic studies of a water-soluble benzodiazepine, midazolam maleate. Anesthesiology 50, 467-70. 윽

Davidson D. L. W. (1980) Anticonvulsant drugs. British Medical fournal 286, $2043-5$.

DeJong R. H. \& Bonin J.D. (1981) Benzodiazepines protect mice from local anaesthetic convulsions $\frac{O}{20} d 0$ death. Anaesthesia and Analgesia 60, 385-9.

Delgado-Escueta A. V., Wasterlain C., Treiman D. M. \& Porter R. J. (1982) Current concepts in neurolog management of status epilepticus. New England fournal of Medicine 306, 1337-40.

Deshmukh A., Wittert W., Schnitzler E. \& Mangurten H. H. (1986) Lorazepam in the treatment of refractoryo neonatal seizures. American fournal of Diseases of Children 140, 1042-4.

Gastaut H., Naquet R., Poire R. \& Tassinari C. A. (1965) Treatment of status epilepticus with diazepam@ (Valium). Epilepsia 6, 167-82.

Meldrum B. S. \& Chapman A. G. (1986) Benzodiazepine receptors and their relationship to the treatment of epilepsy. Epilepsia 27 (Supplement), S3-S13.

Naquet R., Soulayrol R., Dolce G., Tassinari C. A., Broughton R. \& Loeb H. (1965) First attempt ato treatment of experimental status epilepticus in animals and spontaneous status epilepticus in man with diazepam (Valium). Electroencephalography and Clinical Neurophysiology 18, 424-7.

Sunao Kaneko, Kozo Kurahashi, Seiichi Fujita, Yutaka Fukushima, Tokijiro Sato \& Hill R. G. (1983) Potentiation of GABA by midazolam and its therapeutic effect against status epilepticus. Folia Psychiatrica? et Neurologica faponica 37, 307-9. 